\title{
Effect of Moisture Content on Power Generation in Dual Graphene Anode Compost Solid Phase Microbial Fuel Cells (DGACSMFCs)
}

\author{
Ganjar Samudro ${ }^{1, *}$, Syafrudin Syafrudin ${ }^{1}$, Irawan Wisnu Wardhana ${ }^{1}$, Cagayana Cagayana ${ }^{1}$, Meishinta Ariyanti ${ }^{1}$, and Erika \\ Lucitawati $^{1}$ \\ ${ }^{1}$ Department of Environmental Engineering, Faculty of Engineering, Diponegoro University, Semarang - Indonesia
}

\begin{abstract}
Moisture content which affects the decomposition of organic material is one of composting parameters. The optimum moisture content indicates the higher power generation. This research aims to determine the optimum moisture content toward power density during the composting process in DGACSMFCs. The reactor was designed with dual graphene anode placed on the base and a half of reactor height in $2 \mathrm{~L}$ effective volume. Moisture content was varied at $40 \% ; 50 \%$; $60 \%$; with 4 turning frequency, $\mathrm{C} / \mathrm{N}$ ratio 30:1, and the mixed waste-leaves litter and canteen based food waste, during 23 days of the observation time. Other parameters of the composting process such as $\mathrm{pH}$, temperature, C-Organic, N-Total, P-Total, and K-Total were also observed as control parameters. The result shows that the optimum moisture content is $60 \%$ with power density $17.74 \mathrm{~mW} / \mathrm{m}^{2}$, and the final compost characteristics are meet the compost requirement based on SNI 19-7030-2004 about the specification of compost from domestic waste..
\end{abstract}

Keywords: moisture content; power density; compost requirement; dual graphene anode; DGACSMFCs.

\section{Introduction}

Power generation from the bioelectrochemical process in Compost Solid Phase Microbial Fuel Cells (CSMFCs) usually generates lower power density than in liquid or semi-liquid phase of substances or materials. Composting organic materials produce compost as a new product which also recycles organic material to valuable product. Other products that can't be predicted previously are electron (e-) and hydrogen ion $(\mathrm{H}+)$ in which as the energy source. The combination between composting and energy generation using Microbial Fuel Cells (MFCs) is investigated towards its performance of power density and compost parameters. CSMCFs have two functions where are composting and electrical capturing. It also increases the benefit of composting for electron donor as an energy alternative source from the organic waste material. CSMFCs has been widely utilized for the new concept of solid phase microbial fuel cell (SMFC) to observe the electrical performance achieving a maximum current density of $200 \mathrm{~mA} / \mathrm{L}$ when used heat-treated soil and applied biological catalyst [1], $385 \mathrm{~mA} / \mathrm{m} 2$ when used heat-treated garden compost [2], $67 \mathrm{~mW} / \mathrm{m} 2$ when used cow dung [3], $170.81 \mathrm{~mW} / \mathrm{m} 2$ when used household kitchen waste [4], and $264 \mathrm{~mW} / \mathrm{m} 2$ and $1535 \mathrm{~mA} / \mathrm{m} 2$ when used agricultural waste with the addition of bio-enzymes [4].
Therefore CSMFCs can be developed as the green technology which uses waste material to generate electricity directly, recycle waste material to compost, and increase the valuable compost which meets the compost requirement based on SNI 19-7030-2004 about the specification of compost from domestic waste.

Moisture content, turning frequency, $\mathrm{C} / \mathrm{N}$ ratio, and material ratio are the dominant variables of the composting process. The optimum conditions which depend on the material characteristics are $40-60 \%$ of moisture content [6] [7], 4 and 7 times of turning frequency in 15 days [8] [10], 30:1-50:1 of $\mathrm{C} / \mathrm{N}$ ratio [5], and 50:50-75:25 of compostable organic material ratio. Moisture content became the important key in composting due to affecting the composting efficiency [9]. Turning frequency affected moisture content, dry weight, $\mathrm{pH}$, carbon total, nitrogen total, $\mathrm{C} / \mathrm{N}$ ratio, and temperature [10] [11] [12]. One of the important aspects of nutrient balance total is carbon organic to nitrogen ratio or $\mathrm{C} / \mathrm{N}$ ratio [13]. The compostable organic material ratio affects the biodegradability and decomposability [14].

Other parameters affecting the composting process are carbon $(\mathrm{C})$, nitrogen $(\mathrm{N})$, phosphorus $(\mathrm{P})$, and kalium (K). They were periodically observed as a control. The percentage of CNPK is the final result of compost

* Corresponding author: ganjarsamudro@gmail.com 
parameters which may affect the application of compost as the soil conditioner to plants or crop growth.

Dual Graphene Anode Compost Solid Phase Microbial Fuel Cells (DGACSMFCs) uses dual graphene as the anode to enhance the capturing of electron converted to electricity. The more electrodes, the more electricity generated. Graphene has higher surface area than plate graphite carbon which has been widely used as the electrode in many kinds of MFCs researches. It currently is user-friendly and easy homemade. DGACSMFCs performance depends on the optimum conditions and parameters control. The optimum moisture content, turning frequency, $\mathrm{C} / \mathrm{N}$ ratio, and material ratio, the higher power generation. The parameters control the compost requirement which correlates the power generation. The problem is that the moisture content between 40-60\% hasn't been yet observed and correlated to the power generation in DGACSMFCs. This research aims to determine the optimum moisture content towards power density during the composting process in DGACSMFCs.

\section{Methods}

The mixed-leaves litter and canteen based food waste was collected from TPST Undip located at Diponegoro
University Indonesia. Waste samples were collected using Indonesia National Standard 19-3964-1994 about waste sampling method. The waste characteristics were C-Organic, N-Total, P-Total, K-Total, $\mathrm{C} / \mathrm{N}$ ratio, $\mathrm{pH}$, temperature, and moisture content using standard method analysis. River sediment as exoelectrogenic bacteria source was taken from Tanah Mas river Semarang Indonesia.

\subsection{Reactor Design}

DGACSMFCs has one compartment consists of dual graphene anode and cathode which were connected by the electrical circuit and the distance between the cathode and anode is at the base and a half of reactor height. DGACSMFCs reactor was designed by 2-liter volume. Mixed waste volume was $2 / 3$ of reactor volume or 1,330 ml volume. del Campo (2014) [15] stated that the optimum waste volume was $2 / 3$ of total volume of reactor. Sampling point for leachate underdrain was placed beneath of the reactor equipped with a valve. The number of reactors was 24 unit including 8 unit as reactor control and operated in batch condition with the destructive mechanism. DGACSMFCs reactor configuration is described in Fig. 1 as follows:

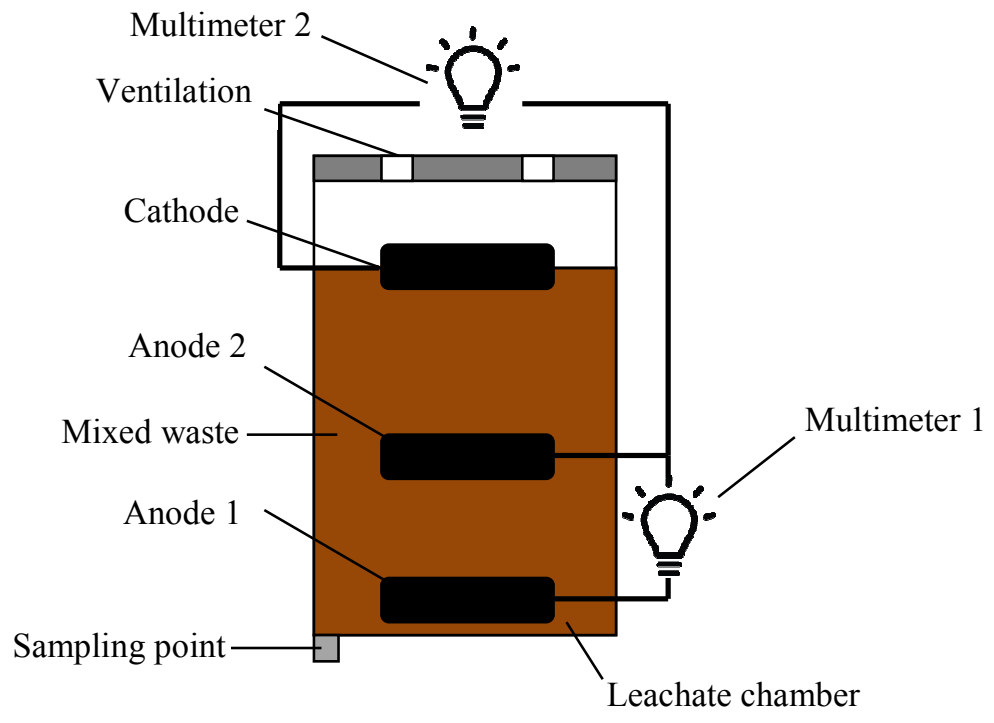

Fig. 1. Reactor Design

\subsection{Tools and Materials}

The tools were spectrophotometer, AAS (Atomic Absorption Spectrofotometer), digital multimeter, $\mathrm{pH}$ meter, thermometer, hot plate, dryer oven, desicator, COD nessler, and centrifuge. The materials were river sediment bacteria, fresh canteen based food waste, plasticware 2-liter volume, mechanical pencil 2B, polyurethane $\mathrm{A}$ and $\mathrm{B}$, phosphate acid $85 \%$, wood glue, sulfate acid 96\% PA, hydrochloric acid $\mathrm{HCl} 0.1 \mathrm{M}$, sodium hydroxide $\mathrm{NaOH} 0.1 \mathrm{M}$, aquadest, and CNPK analysis test (selenium reagent mixture, sulphate acid
$97 \%$, sodium hydroxide $6 \%$, butanedioic acid, nessler reagent, potassium dichromate, nitrate acid $65 \%$, sodium hydroxide $40 \%$, vanadat molibdate, digest solution, and filter paper) .

\subsection{Research Procedure}

The research was divided into three steps which were initial research, the main research, and data analysis. Initial research consists of reactor construction including the making of graphene homemade and initial test. Graphene was initially made by activating and cleaning the aluminum plate with hydrochloric acid $\mathrm{HCl} 0.1 \mathrm{M}$ 
and sodium hydroxide $\mathrm{NaOH} 0.1 \mathrm{M}$, and then continued with the making of pure carbon powder from mechanical pencil 2B blended by polyurethane solution with Carbon/Polyurethane ratio 1:2. The next step is lubricating the mixture of carbon powder and polyurethane on the aluminum plate until dry. The last step is lubricating the dried aluminum plate with a phosphate acid solution $85 \%$ to guarantee the carbon powder sticking firmly onto the aluminium plate [5]. The initial test was conducted for mixed waste and graphene characteristics. The mixed waste characteristics were moisture content, C-Organic, N-Total, P-Total, K-Total, $\mathrm{pH}$, and temperature. The graphene characteristics were voltage, current, and electrical resistance. The main research was conducted by operating DGACMFCs for 8 times with details of 7 unit sampling from 0 days as time control to $23^{\text {rd }}$ day. Sampling time was determined for more than 15 days based on the optimum and stable condition in electrical production from previous research using SMFCs reactor [16]. The equation of power as follows: $\mathrm{P}=\mathrm{I} \times \mathrm{R}$; where $\mathrm{I}$ is the current (ampere) and $\mathrm{R}$ is the applied external resistance (ohm). The equation of current as follows: $\mathrm{I}=\mathrm{V} / \mathrm{R}$; where $\mathrm{I}$ is the current (ampere), $\mathrm{R}$ is the applied external resistance (ohm), and $\mathrm{V}$ is the voltage (volt) [17]. The power density formulation equation as follows: $\mathrm{P}=(\mathrm{V} \times \mathrm{I}) / \mathrm{A}$; where $\mathrm{A}$ is the surface area of graphene anode $\left(\mathrm{m}^{2}\right)$. The voltage is measured using a digital multimeter, and the power density curve is obtained by applying different moisture content and time to the system. Whereas the compost maturity was observed after 23rd day to analyze COrganic, N-Total, P-Total, K-total, $\mathrm{C} / \mathrm{N}$ ratio, $\mathrm{pH}$, temperature, and moisture content using standard methods and compare it to SNI 19-7030-2004 about the specification of compost from domestic waste.

\section{Result and Discussion}

The mixed waste-leaves litter and canteen based food waste have been initially analyzed to know CNPK-pHtemperature containing mixed waste. It has highly biodegradable solid waste [4]. Composting needs $\mathrm{C} / \mathrm{N}$ ratio approximately $25-35$ to accelerate the composting process [19], whereas moisture content is approximately $50-70 \%$ [20]. Other than that $\mathrm{pH}$ affects microorganism growth and the optimum $\mathrm{pH}$ which accelerates the composting process is approximately 6-9 [21]. The result is that mixed waste characteristics meet the requirement of compost raw material and guarantee the composting process to produce electron as an energy product. The following is presented in Table 1.

Table 1. Mixed Waste Characteristics

\begin{tabular}{|c|c|}
\hline Parameters & Result \\
\hline C-Organic (\%) & 36.15 \\
\hline N-Total (\%) & 1.10 \\
\hline P-Total (\%) & 1.08 \\
\hline K-Total (\%) & 0.96 \\
\hline C/N Ratio & 32.79 \\
\hline Moisture Content (\%) & 67.72 \\
\hline $\mathrm{pH}$ & 6.9 \\
\hline
\end{tabular}

The performance of DGACSMFCs is based on two main parameters which are power density and compost characteristics. Power density is representative of power generation, whereas CNPK-pH-temperature is representative of compost characteristics. The correlation of time and moisture content towards power density and compost characteristics is described to determine the optimum moisture content.

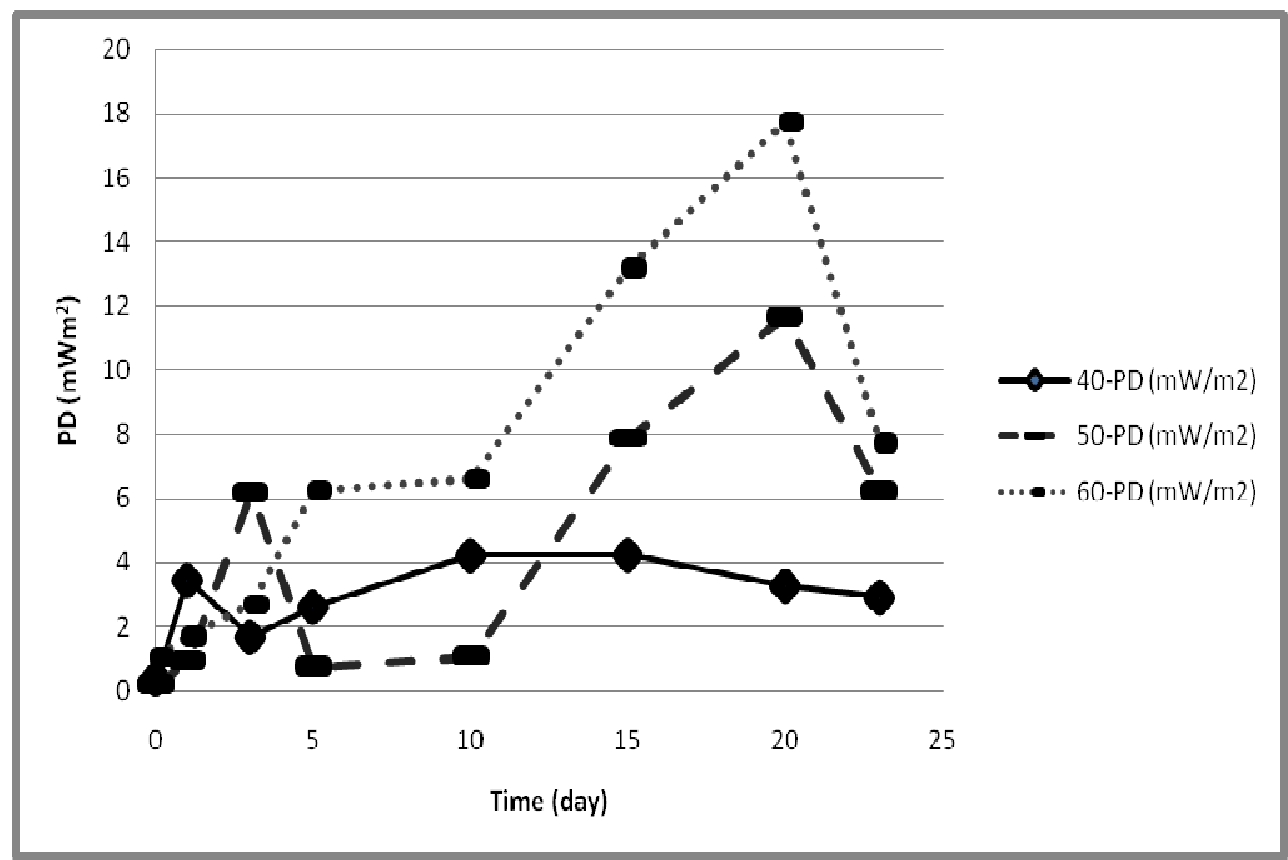

Fig. 2. Correlation of Time and Moisture Content towards Power Density 
At fig. 2. about the correlation of time and moisture content towards power density seen that the higher moisture content, the higher power density. Moisture content is only at $60 \%$ maximum and $40 \%$ minimum due to the optimum of moisture content in composting. The highest power density is $17.74 \mathrm{~mW} / \mathrm{m}^{2}$ of moisture content $60 \%, 4$ turning frequency, $\mathrm{C} / \mathrm{N}$ ratio $30: 1$, and mixed waste at $20^{\text {th }}$ day, whereas the lowest power density is $3.28 \mathrm{~mW} / \mathrm{m}^{2}$ of moisture content $40 \%, 4$ turning frequency, $\mathrm{C} / \mathrm{N}$ ratio $30: 1$, and mixed waste at 20th day. Samudro et al. (2018) [16] found that the highest power density of mixed waste in Solid Phase Microbial Fuel Cells (SMFCs) reached $15^{\text {th }}$ day. It can be stated that the maximum power density in solid phase material in the batch process of Microbial Fuel Cells (MFCs) starts from $15^{\text {th }}$ to $25^{\text {th }}$ day. According to other similar research which was obtained $264.7 \mathrm{~mW} / \mathrm{m}^{2}$ [5] due to the addition of bio-enzymes which increasing 8.5 times respectively of the system. Another CSMFC research using carbon felt as an electrode and the combination of nuts waste, coffee, and rice husk as substrates showed that at moisture content $60 \%$ was obtained power density $4.6 \mathrm{~mW} / \mathrm{m}^{2}$ [7]. Whereas the research conducted using the mixed fruits, vegetables, and soil, with $\mathrm{C} / \mathrm{N}$ ratio $24: 1$ was obtained power density $5.29 \mathrm{~mW} / \mathrm{m}^{2}$ [22]. This research increases 3-4 times respectively of the system.

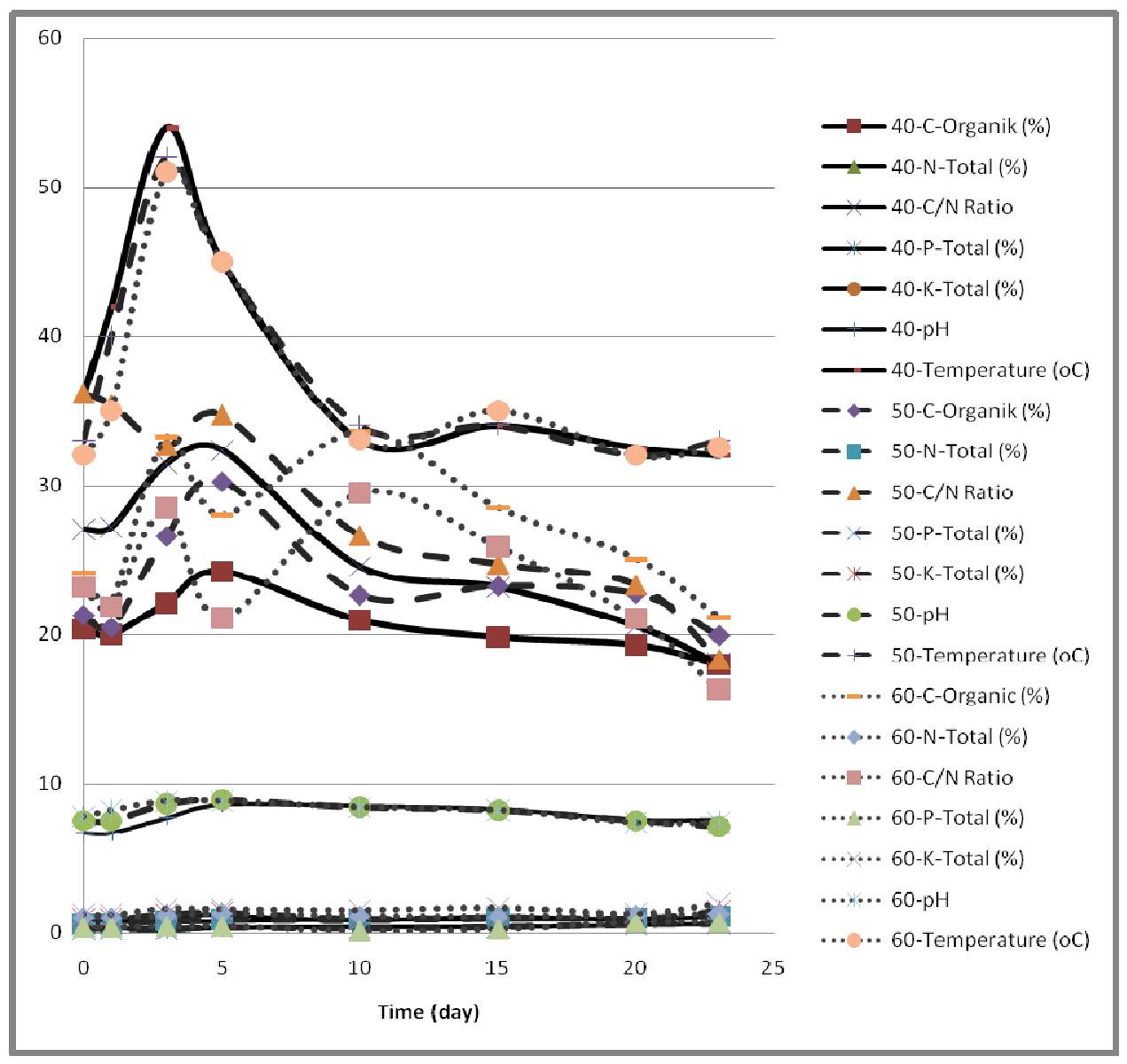

Fig 3. Correlation of Time and Moisture Content towards Composting Characteristics

Based on SNI 19-7030-2004, the standard quality of compost as macro element consist of maximum moisture content $50 \%$, groundwater temperature, $\mathrm{pH}$ 6.80-7.49, minimum nitrogen $0.4 \%$, carbon $9.80-32 \%$, minimum phosphor $\left(\mathrm{P}_{2} \mathrm{O}_{5}\right) 0.10 \%, \mathrm{C} / \mathrm{N}$ ratio $10-20$, and minimum kalium $\left(\mathrm{K}_{2} \mathrm{O}\right) 0.20 \%$. At Fig.3. about the correlation of time and moisture content towards composting characteristics seen that at final day ( $23^{\text {rd }}$ day), all macro element meet the standard quality of compost. It can be stated that the standard quality of compost meets the requirement of SNI 19-7030-2004 when the composting process time up to $20^{\text {th }}$ day.
The correlation between the power density and compost characteristics can be determined at $20^{\text {th }}$ day to know the inline performance. The highest power density result at $20^{\text {th }}$ day reach the optimum compost requirement as follows: $\mathrm{PD}=17.74 \mathrm{~mW} / \mathrm{m}^{2} ;$ C-Organic $=25.07 \%$; NTotal $=1.19 \% ; \mathrm{C} / \mathrm{N}$ ratio $=21.05 ; \mathrm{P}-$ Total $=0.71 \% ; \mathrm{K}-$ Total $=1.31 \% ; \mathrm{pH}=7.4$; and Temperature $=32{ }^{\circ} \mathrm{C}$. After $20^{\text {th }}$ day, the power density decreased slowly as same as the changing compost characteristics. The accumulation power density at $60 \%$ of moisture content is $56.95 \mathrm{~mW} / \mathrm{m}^{2}$ for 23-day process.

The power density of mixed waste in DGACSMFCs is less than composite waste in SMFCs and agricultural

\footnotetext{
* Corresponding author: ganjarsamudro@gmail.com
} 
waste in CSMFC. The difference among DGACSMFCs, SMFCs, and CSMFC is lots of water, a number of the anode, and the bio-enzymes addition which affects the performance.

The authors wish to thank the Research and Development Institutions of Diponegoro University for funding this research with a Research on the Development and Application of sources of funds other than APBN scheme in 2018.

\section{Conclusion}

The optimum moisture content of 4 turning frequency, $\mathrm{C} / \mathrm{N}$ ratio $30: 1$, and mixed waste-leaves litter and canteen based food waste is $60 \%$ with power density $17.74 \mathrm{~mW} / \mathrm{m}^{2}$. The higher moisture content, the higher power density. The final compost characteristics are also meet the compost requirement based on SNI 19-70302004 about the specification of compost from domestic waste. CSMFCs using waste material as the green technology can be the valuable choice to produce electricity efficiently and also qualified compost.

\section{References}

1. Niessen J, Harnisch F, Rosenbaum M, Uwe S, Fritz $\mathrm{S}$. Heat treated soil as convenient and versatile source of bacterial communities for microbial electricity generation. Electrochem Commun; 8(5):869-73 (2006).

2. Parot S, De'lia ML, Bergel A. Forming electrochemically active biofilms from garden compost under chronoamperometry. Bioresour Technol;99(11):4809-16 (2008).

3. Lee Y, Nirmalakhandan N. Electricity production in membrane-less microbial fuel cell fed with livestock organic solid waste. Bioresour Technol;102:5831-5 (2011).

4. Mohan SV, Chandrasekhar K. Solid phase microbial fuel cell (SMFC) for harnessing bioelectricity from composite food waste fermentation: Influence of electrode assembly and buffering capacity. Bioresour Technol;102:7077-85 (2011).

5. Wang CT, Liao FY, Liu KS. Electrical analysis Electrical Analysis of Compost Solid Phase Microbial Fuel Cell. International Journal of Hydrogen Energy; 38: 11124-11130 (2013).

6. Hoitink HAJ, Stone AG, Han DY. Suppression of plant Diseases by Composts. HortSci; 32: 184-187 (1997).

7. Wang, C. T., Lee, Y. C., Liao, F. Y. Effect of composting parameters on the power performance of solid microbial fuel cells. Sustainability (Switzerland), 7(9), 12634-12643(2015).

8. Tchobanoglous, G., Theisen, H. and Vigil, S.A. Integrated Solid Waste Management: Engineering Principle and Management Issue. McGraw Hill Inc., New York (1993).
9. Luo, W., Chen, T.B.. Effects of moisture content of compost on its physical and chemical properties. Acta. Ecol. Sin.; 24: 2656-2663 (2004).

10. Tiquia S.M., Tama N.F.Y., Hodgkiss I.J. Effects of turning frequency on composting of spent pigmanure sawdust litter. Bioresource Technology; 62 (1-2): 37-42 (1997).

11. Wong, J.W.C., K.F. Mak, N.W. Chan, A. Lam, M. Fang, L.X. Zhou, Q.T. Wu and X.D. Liao. Cocomposting of soybean residues and leaves in Hong Kong. Bioresource Technology; 76 (2): 99-106 (2001).

12. Ogunwande G. A., Osunade J. A.,. Ogunjimi L.A.O. Effects of Carbon to Nitrogen Ratio and Turning Frequency on Composting of Chicken Litter in Turned-Windrow Piles. Agricultural Engineering International: the CIGR Ejournal. Manuscript EE 07 016. Vol. X. July (2008).

13. Widarti, B. N., Wardhini, W. K., Sarwono, E. Pengaruh Rasio C/N Bahan Baku Pada Pembuatan Komppos Dari Kubis Dan Kulit Pisang. Integrasi Proses, 5(2), 77 (2015).

14. Mangkoedihardjo S., April SAL. Compost On Evapotranspiration Bed Planted With Yellow Flag For Treatment Of Wastewater Containing Anionic Surfactant. Journal of Applied Sciences Research; 8(3): 1630-1633 (2012).

15. del Campo, GA., Perez, J. F., Ca, P., Rodrigo, M. A., Fernandez, F. J., Lobato, J.. Study of a photosynthetic MFC for energy recovery from synthetic industrial fruit juice wastewater; 9, 0-8 (2014).

16. Samudro G., Syafrudin S., Nugraha WD., Sutrisno E., Priyambada IB., Muthi'ah H., Sinaga GN., Hakiem RT. The Effect of COD Concentration Containing Leaves Litter, Canteen and Composite Waste to The Performance of Solid Phase Microbial Fuel Cell (SMFC). E3S Web Conf.; 31(5) (2018).

17. Kim, J., Kim, K., Ye, H., Lee, E., Shin, C., McCarty, P.L., Bae, J.. Anaerobic fluidized bed membrane bioreactor for wastewater treatment. Environ. Sci. Technol; 45 (2), 576-581 (2011).

18. Chen X.X. Composting technology and equipment manuals and case assembly. Industrial Development Bureau Ministry of Economic Affairs Publishing; Taipei, Taiwan (2005).

19. Liang, C.; Das, K.C.; McClendon, R.W. The influence of temperature and moisture contents regimes on the aerobic microbial activity of a biosolids composting blend. Bioresour. Technol; 86: 131-137 (2003).

20. Nakasaki, K.; Yaguchi, H.; Sasaki, Y.; Kubota, H. Effects of pH Control on Composting of Garbage. Waste Manag. Res.; 11: 117-125 (1993).

21. Khudzari, Jauharah Md; Tartakovsky, Boris; Raghavan, G.S. Vijaya. Effect of $C / N$ ratio and salinity on power generation in compost microbial fuel cells. Waste Management (2015). 